\section{Molecular aspects during seed germination of Erythrina velutina Willd. under different temperatures (Part 2): isoenzyme activity and DNA integrity}

\author{
Francival Cardoso Felix ${ }^{1}$ iD, Josenilda Aprígio Dantas de Medeiros $^{1}$ (iD, \\ Cibele dos Santos Ferrari ${ }^{1}$, Mauro Vasconcelos Pacheco ${ }^{1 *}$ (iD), Salvador \\ Barros Torres ${ }^{2}$ iD
}

ABSTRACT: Erythrina velutina Willd. (Fabaceae) is a Brazilian native tree with economic, ecological and social potential. The aim of this study was to evaluate isoenzyme activity and changes in DNA integrity during germination of $E$. velutina at different temperatures. The seeds were placed to germinate at $5,15,25,35$ and $45^{\circ} \mathrm{C}$, evaluating isoenzyme activity and degradation of the DNA during germination. Isoenzyme expression occurs differently for seed germination under different temperatures, with varied expression between seedlings and cotyledons. The esterase enzyme was more sensitive to express the response of the $E$. velutina germination seeds at different temperatures. DNA repair is more efficient during the germination of $E$. velutina seeds when submitted to a temperature of up to $25^{\circ} \mathrm{C}$, with damage to the genetic apparatus with an increase higher than this temperature.

Index terms: DNA repair, seed biochemical, germination ecophysiology, forest seeds.

Aspectos moleculares durante a germinação de sementes de Erythrina velutina Willd. sob diferentes temperaturas (Parte 2): atividade isoenzimática e integridade do DNA

RESUMO: Erythrina velutina Willd. (Fabaceae) é uma espécie nativa brasileira com potencial econômico, ecológico e social. $\mathrm{O}$ objetivo deste estudo foi avaliar a atividade de isoenzimas e as alterações na integridade do DNA durante a germinação de $E$. velutina em diferentes temperaturas. As sementes foram colocadas para germinar a $5,15,25,35$ e $45^{\circ} \mathrm{C}$, avaliandose atividade isoenzimática e a degradação do DNA durante a germinação. A expressão isoenzimática ocorre de maneira diferente para a germinação das sementes sob diferentes temperaturas, com expressão variada entre plântulas e cotilédones. A enzima esterase foi mais sensivel para expressar a resposta de sementes de $E$. velutina sob diferentes temperaturas de germinação. O reparo do DNA é mais eficiente durante a germinação das sementes de $E$. velutina quando submetidas à temperatura de até $25^{\circ} \mathrm{C}$, com prejuizo ao aparato genético em temperaturas superiores.

Termos para indexação: reparo do DNA, bioquímica de sementes, ecofisiologia da germinação, sementes florestais.
Journal of Seed Science, v.42, e202042000, 2020

http://dx.doi.org/10.1590/ 2317-1545v42234879
${ }^{*}$ Corresponding author
E-mail: pachecomv@hotmail.com

Submitted: $3 / 8 / 2020$

Accepted: 4/16/2020

${ }^{1}$ Unidade Acadêmica Especializada em Ciências Agrárias, Universidade Federal do Rio Grande do Norte (UFRN), RN 160, Km 03 - Distrito de Jundiaí, 59280-000, Macaíba, Rio Grande do Norte, Brasil.

${ }^{2}$ Departamento de Ciências Agronômicas e Florestais, Universidade Federal Rural do Semiárido (UFERSA), Rua Francisco

Mota, 572 - Pres. Costa e Silva, 59625-900, Mossoró, Rio Grande do Norte, Brasil. 


\section{INTRODUCTION}

Erythrina velutina Willd. (Fabaceae) is a Brazilian native tree (Rodrigues et al., 2018). Its bark is used as a tranquilizer extract (Candido et al., 2015) and has an anxiolytic hydroalcoholic effect (Sousa et al., 2018). The leaf extracts contain phenols, tannins, alkaloids, flavonoids, sterols, triterpenoids, catechins, saponins and xanthones (Palumbo et al., 2016, Rodrigues et al., 2017).

Despite the social, ecological and economic importance of $E$. velutina to the Northeast region of Brazil (Caatinga and Cerrado phytogeographic domains), there is still little information on this species, especially related to the physiological and biochemical aspects during germination. In this process, unfavorable environmental conditions have been affecting the initial establishment and development in the field.

The temperature directly affects the biochemical reactions of regulating the seed metabolism, influencing the germination and its speed (Gonçalves et al., 2015). These events are mainly due to the regulation of cellular respiration intensity in mitochondria and the enzymatic activity (Marcos-Filho, 2015). In this sense, the optimal germination temperature is that for which the seed expresses its maximum germination performance, while the minimum and the maximum are characterized by lower germination, at which germination does not occur at below or above it (Bewley et al., 2013).

The effect of temperature on seedling development can be associated with the hydrolysis of reservations and enzymatic expression. The high temperatures reduce seed germination due to deteriorative processes, protein denaturation and inactivation of enzymes (Catão et al., 2016; Dubal et al., 2016). Furthermore, different seedling organs demonstrate different enzyme activities responses to temperature during germination (Henson et al., 1980).

In this context, the determination of the isoenzyme activity has been used to complement physiological seed analyzes, considering more researched isoenzymes that act in the respiratory process, specific enzymes of the lipid metabolism, those involved in the nitrogen-carbon metabolism, in addition to enzymes related to destructuring of the membrane system (Carvalho et al., 2000). Thus, it is recommended to evaluate different isoenzyme systems to better understand the effect of temperature on seed performance.

The integrity of the genetic material also plays an important role in the first hours of germination (Sano et al., 2016). This characteristic is involved in the control of several essential cellular processes, and its degeneration causes damage and death of the seeds (Waterworth et al., 2019). Therefore, studies that take this approach into account are necessary.

The scarcity of research on the molecular aspects in seeds of forest species is well-known, especially those linked to the influence of environmental factors such as temperature. In this sense, the aim of this study was to evaluate isoenzyme activity and changes in DNA integrity during the germination of E. velutina seeds at different temperatures.

\section{MATERIAL AND METHODS}

The study was developed with lots of $E$. velutina seeds coming from the municipality of Ilhéus, Bahia State, Brazil. Seeds were acquired commercially (> 70\% viability) in 2017 and kept in a $4{ }^{\circ} \mathrm{C}$ refrigerator until the execution of this experiment. Germination tests of $E$. velutina were performed with four replications of 50 seeds, using paper towel substrate (Germitest ${ }^{\circledR}$ ), moistened with distilled water in the amount equivalent to three times the dry mass of the paper (Brasil, 2009). The seeds were previously scarified in the region opposite to the micropyle by means of iron sandpaper and sown. Then the paper rolls with the seeds were kept in a Biochemical Oxygen Demand (BOD) type germinator at $5,15,25,35$ and $45^{\circ} \mathrm{C}$ with a photoperiod of $12 \mathrm{~h}$.

Isoenzyme activity: The seeds were placed to germinate in the same procedure as the germination test at temperatures of 15,25 and $35^{\circ} \mathrm{C}$. Ten biological replications were collected for each temperature after 20 days to extract isoenzymes from the seedling and cotyledon, in addition to the dry seed. The extraction and electrophoresis methodology was adapted from Scandalios (1969), wherein a sample $200 \mathrm{mg}$ of plant material was weighed, macerated in an ice bath with extraction buffer $(0.2 \mathrm{M}$ lithium borate at $\mathrm{pH} 8.3$, Tris citrate and $0.2 \mathrm{M}$ at $\mathrm{pH} 8.3$, plus $0.15 \%$ of 2-mercaptoethanol) in the ratio $1: 2\left(\mathrm{~m} . \mathrm{v}^{-1}\right)$, and placed overnight at $10^{\circ} \mathrm{C}$. After, the samples were centrifuged at $12,000 \mathrm{rpm}$ for $30 \mathrm{~min} ; 20 \mu \mathrm{L}$ 
of the supernatant was collected and applied on $8 \%$ polyacrylamide gel. Electrophoresis was run in a vertical vial using $0.2 \mathrm{M}$ lithium borate buffer at $80 \mathrm{~V}$ for $2 \mathrm{~h}$. Gel development systems were according to Scandalios (1969) for esterase (EST) and glutamate oxalacetate transaminase (GOT) enzymes, and according to Alfenas (1998) for alcohol dehydrogenase (ADH), glutamate dehydrogenase (GTDH) and sorbitol dehydrogenase (SBTDH). The isoenzymatic activity was visually evaluated in according the presence or absence and intensity of bands' expression, by a white light transilluminator. For the visual analysis of the gels there were no statistical analyses.

Integrity of the DNA during the germinative process: Two times ( 24 and $72 \mathrm{~h}$ ) were defined to make the samples according to the water absorption pattern by the seeds at temperatures of $5,15,25,35$ and $45^{\circ} \mathrm{C}$, in addition to the dry seed. The threephase water absorption pattern was obtained by weighing 100 seeds in an analytical scale $(0.001 \mathrm{~g})$. The seeds were placed under the same conditions as those used in the germination test described above during the period of $78 \mathrm{~h}$.

Ten-seed embryonic axes for each temperature were extracted at 24 and $72 \mathrm{~h}$ after sowing. These were stored in tubes containing $2 \%$ CTAB (cetyltrimethylammonium bromide) and stored in a freezer at $-20{ }^{\circ} \mathrm{C}$. The DNA was extracted according to Doyle and Doyle (1987) protocol, quantified in spectrophotometer (Epoch $\left.{ }^{\mathrm{TM}}\right)$ (260/280 purity ratio of $1.26 \pm 0.11$ between samples) and the results expressed in DNA concentration (ng. $\left.\mu \mathrm{L}^{-1}\right)$ dry weight $^{-1}$. Then, $5 \mu \mathrm{L}$ of the DNA from each treatment was stained with $4 \mu \mathrm{L}$ of bromephenol and Gelred ${ }^{\mathrm{TM}}$ blue, which was then inserted into agarose gel $\left(1.0 \mathrm{~m} \cdot \mathrm{v}^{-1}\right)$ and run into a horizontal electrophoresis cell, in addition to a standard molecular weight sample of $1 \mathrm{~Kb}$ (Ladder Kasvi ${ }^{\circ}$ ). The agarose gel was then immersed in 1X TAE buffer (Tris-acetate-EDTA) and fed by a $100 \mathrm{~V}$ electric current for $1 \mathrm{~h}$. Finally, the photograph was captured under ultraviolet light in photodocumenting equipment (E-Box VX2).

Statistical analysis: The experiment was conducted in a completely randomized design with analysis of variances (ANOVA) performed using the BioEstat ${ }^{\circledR} 5.0$ statistical program, as well as mean comparisons by the Tukey test at the level of $5 \%$ of probability.

\section{RESULTS AND DISCUSSION}

The enzyme alcohol dehydrogenase (ADH) only showed activity in the cotyledons of $E$. velutina when the seeds germinated at 15 and $25^{\circ} \mathrm{C}$ (Table 1). This activity was of low intensity and can also be verified in the dry seed, where the expression of 3 alleles was observed. The seedling did not express this isoenzyme at any of the evaluated temperatures, similarly to the work of Tunes et al. (2011), in which the ADH activity was quite pronounced in the seeds, whereas it was practically null in the seedlings.

The ADH enzyme is involved in anaerobic metabolism, catalyzing the reduction of aldehyde to ethanol, a compound less toxic to the plant (Kato Noguchi and Yasuda, 2007). This enzyme is stored in the seed during the maturation process, and remains stable until germination begins, and its metabolism is reactivated in phases I and II of imbibition. Their levels decrease drastically after imbibition (Weitbrecht et al., 2011), indicating the predominance of the aerobic process of energy generation. This is consistent with the low intensity of $A D H$ expression observed in the electrophoretic profile from $E$. velutina cotyledons after 20 days of seed imbibition. It is also consistent with the lack of activity of this enzyme when germinated seeds were evaluated at $35^{\circ} \mathrm{C}$, with their development anticipated by the temperature increase as morphologically observed in Figure 1 in the part 1 (stage II), accelerating ADH consumption and establishing the totally aerobic respiratory process, where this enzyme is no longer necessary. It can also be considered that the maintenance of the ADH activity at 25 and $30^{\circ} \mathrm{C}$ was favorable to the germinative processes, because it reduces the exposure of the seeds to the deleterious action of acetaldehyde.

Studies demonstrate that de novo synthesis of ADH can be induced under cold stress conditions, and then this enzyme is quantitated expressively in seedling tissues (Kato Noguchi and Yasuda, 2007; Mertz et al., 2009; Weitbrecht et al., 2011). However, this was not verified in the present research when $E$. velutina seeds germinated at $15^{\circ} \mathrm{C}$, probably because this native species did not present evolutionary adaptation of tolerance to cold stress since its occurrence is in regions with higher temperatures. 
Table 1. Isoenzymes alcohol dehydrogenase $(A D H)$, esterase (EST), glutamate oxalacetate transaminase (GOT), glutamate dehydrogenase (GTDH) and sorbitol dehydrogenase (SBTDH) expressed in Erythrina velutina seeds germinated at 15,25 and $35{ }^{\circ} \mathrm{C}$ in the cotyledons and seedlings, in addition to the dried seed.

\begin{tabular}{|c|c|c|c|c|c|c|c|c|}
\hline \multirow{2}{*}{\multicolumn{2}{|c|}{ Isoenzymes }} & \multicolumn{3}{|c|}{ seedling } & \multicolumn{3}{|c|}{ cotyledons } & \multirow{2}{*}{ dry seed } \\
\hline & & $15^{\circ} \mathrm{C}$ & $25^{\circ} \mathrm{C}$ & $35^{\circ} \mathrm{C}$ & $15^{\circ} \mathrm{C}$ & $25^{\circ} \mathrm{C}$ & $35^{\circ} \mathrm{C}$ & \\
\hline \multirow{3}{*}{$\mathrm{ADH}$} & & & & & & & & \\
\hline & & & & & & & & \\
\hline & & & & & & & & \\
\hline \multirow{4}{*}{ EST } & & & & & & & & \\
\hline & & & & & & & & \\
\hline & & & & & & & & \\
\hline & & & & & & & & \\
\hline GOT & & & & & & & & \\
\hline \multirow{4}{*}{ GTDH } & & & & & & & & \\
\hline & & & & & & & & \\
\hline & & & & & & & & \\
\hline & & & & & & & & \\
\hline \multirow[t]{5}{*}{ SBTDH } & & & & & & & & \\
\hline & extrem & & & & & & & \\
\hline & weak & & & & & & & \\
\hline & moder & & & & & & & \\
\hline & intense & & & & & & & \\
\hline
\end{tabular}

In analyzing the isoenzyme patterns of the esterase enzyme (EST), it was possible to observe the presence of 4 lowintensity alleles in tissues, seedlings and cotyledons: allele 1 in cotyledons that developed at $25^{\circ} \mathrm{C}$; allele 2 in seedlings at $25^{\circ} \mathrm{C}$; allele 3 in seedlings and cotyledons at $25^{\circ} \mathrm{C}$; and allele 4 in seedlings at 15 and $25^{\circ} \mathrm{C}$, and cotyledons at $15^{\circ} \mathrm{C}$. Its expression was not observed at $35^{\circ} \mathrm{C}$, nor in dry seed (Table 1 ).

Esterase enzymes have been isolated and purified from various sources, including plants, animals and microorganisms. Esterase enzymes present many isoforms, representing a complex group of hydrolytic enzymes that have the overlapping property of specific substrates, hydrolyzing both endogenous and exogenous esters (Bhavitk et al., 2014). Regarding the isoenzymes evaluated in this study, the esterase enzymes were those that presented the highest number of alleles, and consequently express more isoforms of this enzyme. Furthermore, the esterase enzyme was more sensitive test, resulting in different electrophoretic profile for each treatment evaluated. According to Gillespie and Langley (1974), this is one of the most polymorphic isoenzymatic systems observed in plants.

As the enzymes involved in the ester hydrolysis reactions, they are directly linked to lipid metabolism during the germination process, as well as total cell membrane phospholipids (Santos et al., 2005). No esterase expression was observed in the dried seeds of $E$. velutina in this study, probably due to a minimal amount of this enzyme and the methodology used was not sensitive enough to detect it in medium to dry seed substrate. The low concentration of esterase enzymes reflected in the low intensity of the bands in the polyacrylamide gel and in the absence thereof, is probably decreasing the mobilization of lipids during seed germination, resulting in the accumulation of these compounds, as observed in Figure $2 \mathrm{E}$ in the part 1.

The decrease in the number and intensity of bands in the development of esterase enzyme in seeds stored for more than 6 months at 10 and $25^{\circ} \mathrm{C}$ was reported by Vieira et al. (2013). Therefore, the storage period of the seeds prior to 
carrying out the present study with $E$. velutina may also have influenced the absence of esterase expression in the dry seed, since these enzymes act on the metabolism of phospholipids present in the membranes, their consumption is associated with the first events responsible for the aging of seeds.

As verified in Table 1, there was no esterase expression when the seeds germinated at $35^{\circ} \mathrm{C}$. Parasa et al., (2018) verified that esterase enzymes are stable in several species at temperatures above this, for example: in tomato, zucchini and tamarind at $40^{\circ} \mathrm{C}$, and in Sesbania grandiflora (L.) Poiret and Jatropha curcas (L.) at $50^{\circ} \mathrm{C}$. These authors state that plant enzymes generally have optimum temperature in the range of 30 to $40{ }^{\circ} \mathrm{C}$. Thus, it is assumed that the absence of ADH and EST activity, as well as glutamate oxalate transaminase (GOT) and sorbitol dehydrogenase (SBTDH) is not due to an instability caused by the high temperature, but to an acceleration of the metabolism which led to the consumption of these enzymes in the early stages of the germination process of $E$. velutina, and their presence was not observed at the time the samples were analyzed (20 days after imbibition). An indicative of this metabolic acceleration is the high germination speed at $35^{\circ} \mathrm{C}$ associated with the shorter length of seedlings developed at this temperature.
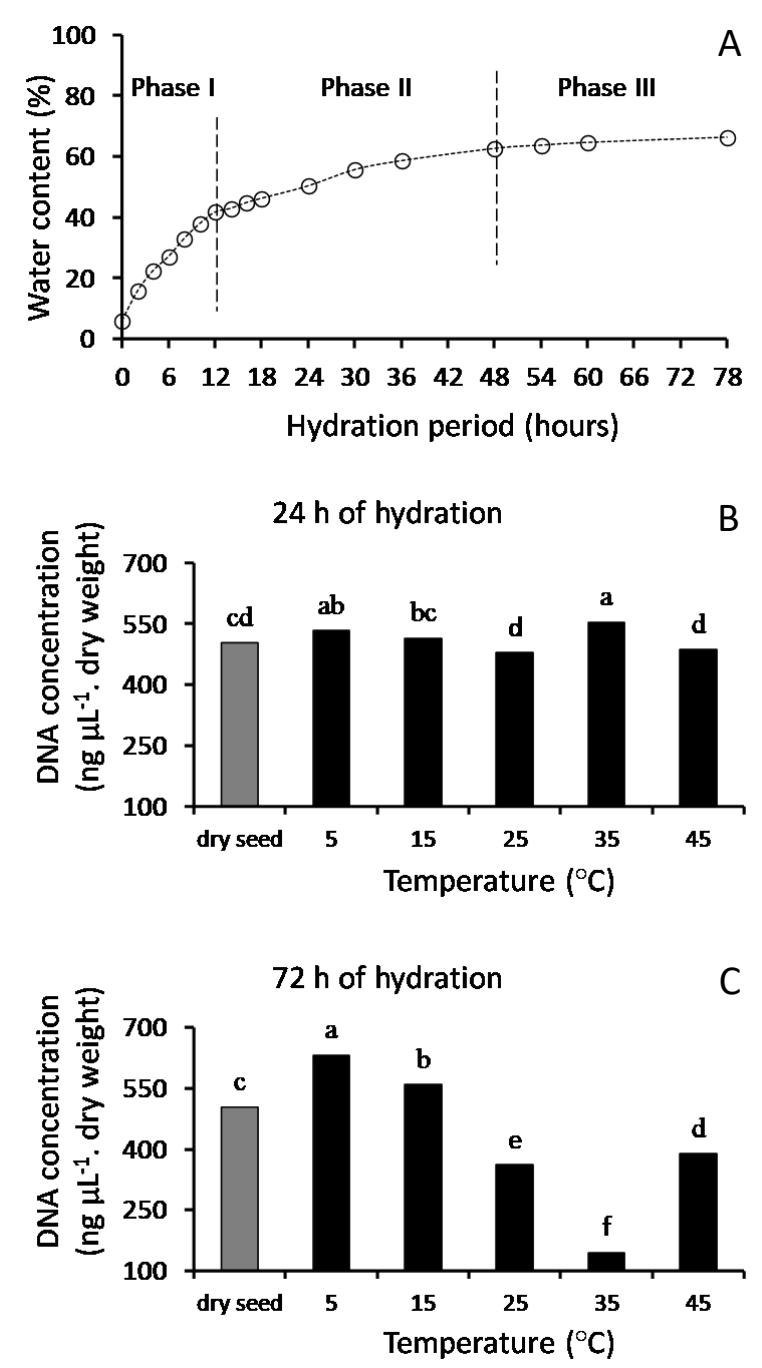

Averages followed by the same letter do not differ by the Tukey test at the $5 \%$ probability level.

Figure 1. (A) Three-phase water absorption and DNA concentration in embryonic axes of Erythrina velutina seeds submitted to germination at different exposure temperatures $\left(5,15,25,35\right.$ and $45{ }^{\circ} \mathrm{C}$ and seed without hydration) for (B) $24 \mathrm{~h}$ and (C) $72 \mathrm{~h}$. 


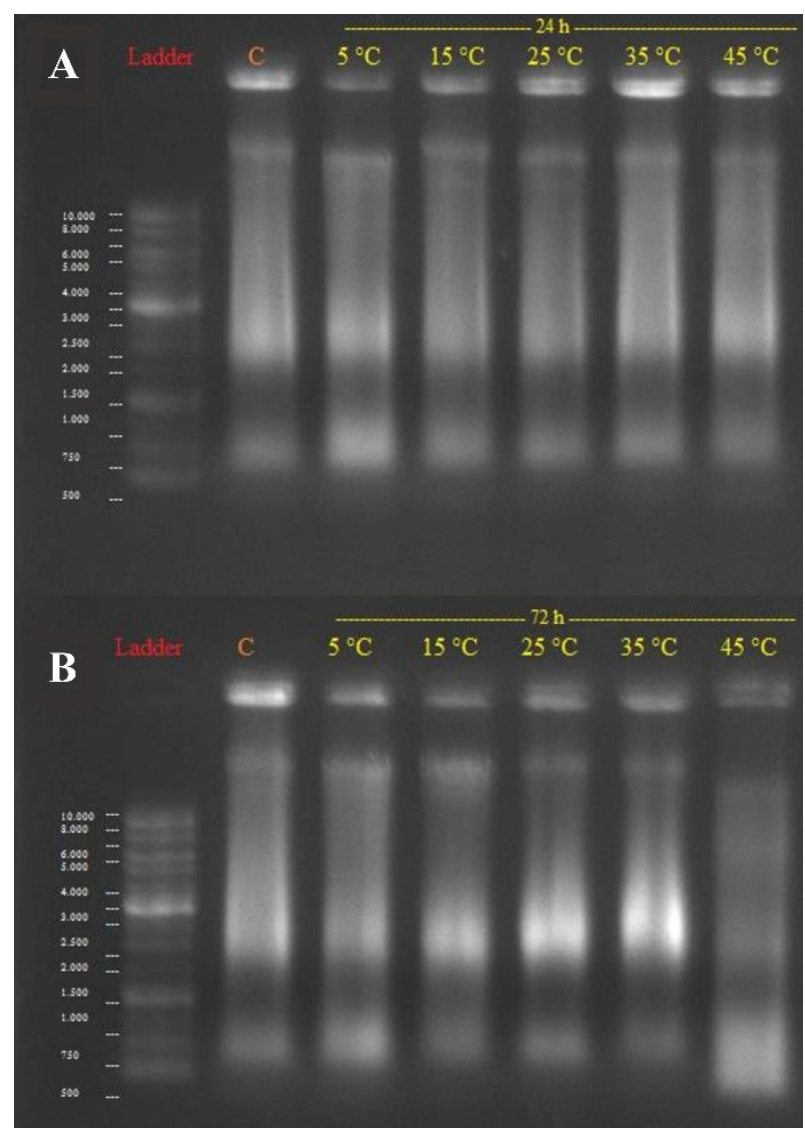

Figure 2. Electrophoresis of embryonic axes of Erythrina velutina seeds submitted to germination at different exposure temperatures $\left(5,15,25,35\right.$ and $\left.45^{\circ} \mathrm{C}\right)$ for $(A) 24 \mathrm{~h}$ and (B) $72 \mathrm{~h}$. C: seed without hydration.

In the study by Malone et al. (2007), the decrease and absence of bands were related to the faster catabolism in rice varieties, suggesting that most of the reserve compounds had been metabolized at seven days of germination. The enzyme glutamate oxalacetate transaminase (GOT) showed intense activity in seedlings and cotyledons, both in seeds germinated at $15^{\circ} \mathrm{C}$ and at $25^{\circ} \mathrm{C}$. This activity was represented by a single allele, expressed in both seedlings and cotyledons. It was also observed that its expression was extremely pronounced in the dried seeds.

GOT is directly involved in the metabolism of nitrogen, acting in a specific transfer reaction of the aminogroup of an amino acid to the $\alpha$-ketoglutaric acid to form the glutamic acid and to produce the keto acid, in a reversible reaction (Conn and Stumpf, 1990). Thus, this enzyme is expressed in both the oxidation of amino acids involved in generating energy via the Krebs cycle and in the reduction of $\alpha$-ketoglutarate, destined to the biosynthesis of new amino acids (Malone et al., 2007). In the present study, intense GOT expression can be observed at temperatures of 15 and $25{ }^{\circ} \mathrm{C}$, indicating that the metabolism processes of reserve proteins and synthesis of amino acids destined to resume embryo growth are active, whereas at $35^{\circ} \mathrm{C}$ these processes involving GOT had ceased at 20 days of germination.

The isoenzymatic profile of glutamate dehydrogenase (GTDH) represents activity of this enzyme in the three evaluated germination temperatures for E. velutina in the seedling, as well as the cotyledons and dry seeds. The number of alleles and the band intensity presented a variation, observing 1 allele in the seedlings, whereas 4 alleles are identified in the cotyledons and dry seeds (Table 1 ).

Glutamate dehydrogenase is an enzyme that links both of those metabolic pools within a cell, as it can carry out the reaction of reductive amination of 2-oxoglutarate to glutamate (the anabolic activity; NADH-GDH), and the reverse reaction of oxidative deamination of glutamic acid (the catabolic activity; NAD+-GDH) (Grabowska et al., 2011).

It is noteworthy that among the enzymes under study, GTDH was the only one that was expressed at $35^{\circ} \mathrm{C}$ at 
20 days of germination, despite the low viability of seeds at this germination temperature (Table 1 in the part 1). High temperatures and ageing promote nitrogen remobilization, a typical feature of the senescence process, and glutamate dehydrogenase may be of particular importance in the catabolism of amino acids to release ammonia for their incorporation into amides during nitrogen remobilization (Haba et al., 2014).

The sorbitol dehydrogenase enzyme was only expressed in seed cotyledons germinated at 15 and $25{ }^{\circ} \mathrm{C}$ and in the dry seed, with 1 low intensity allele. Considering the electrophoretic profiles analyzed, it is possible to verify that the expression of the same enzyme is differentiated between the germinated seed and the dry one, since different cell differentiation and gene expression processes are occurring. Intense metabolic activity is observed during the germination process corresponding to ATP production, the degradation of proteins and reserve polysaccharides, the synthesis of new mRNAs, and the restructuring and repair of damaged membranes and organelles which considerably modifies the isoenzymatic expression, while the dry seed maintains low metabolic activity, referring to the necessary biosynthetic reactions for cellular respiration (Malone et al., 2007).

Regarding the DNA integrity during the germination process, the $E$. velutina seeds present a three-phase water absorption pattern. Phase I lasted 12 hours, followed by Phase II with 36 hours, at which point root protrusion ( 48 hours after sowing) was observed, indicating the beginning of Phase III (Figure 1A). The evaluation of the three-phase water absorption pattern predicts which biochemical and physiological processes are occurring during seed rehydration, initially governed by physical force (Phase I), followed by metabolic activity intensification (Phase II) and embryo growth resumption (Phase III) (Bewley et al., 2013).

E. velutina embryos showed little change in DNA concentration (Figure 1B) and integrity (electrophoresis of embryonic axes of seeds) of the genetic material in the first 24 hours of hydration (Phase II) (Figure 1A), regardless of incubation temperature, although decreases in DNA concentration were checked at 25 and $45^{\circ} \mathrm{C}$ (Figure $1 \mathrm{~B}$ and $1 \mathrm{C}$ ). High temperatures after 72 hours of hydration (Phase III) caused damage to the genetic material until the total collapse of the seed at $45^{\circ} \mathrm{C}$, while temperatures of 5 and $15^{\circ} \mathrm{C}$ maintained the superior DNA integrity compared to the dried seeds (Figure $1 \mathrm{C}$ and Figure 2B). Temperatures near $50^{\circ} \mathrm{C}$ is in the ideal range of activity for numerous enzymes and chemical reactions related to DNA degradation processes (Kranner et al., 2011). Therefore, the seeds kept at $45^{\circ} \mathrm{C}$ in this study completely lost viability.

Therefore, there is a limitation in DNA repair activity at elevated temperatures ( 35 and $45^{\circ} \mathrm{C}$ ). These conditions result in the loss of capacity to produce normal seedlings and to allocate energy reserves. Although DNA damage occurs at $25{ }^{\circ} \mathrm{C}$, embryos are able to produce normal seedlings and efficiently allocate their reserves, which means they repair their genetic material for numerous cellular processes. In this sense, research conducted to evaluate DNA integrity in forest seeds was carried out in Campomanesia adamantium (Cambess.) O. Berg (Dresch et al., 2015) and during the desiccation process, where there were alterations in the integrity of the genetic material. However, these studies are still incipient, not expressive and need to be applied using other species.

Given this outline, it is possible to affirm that the molecular analyzes presented herein contribute to understand the complexity of events that occur during seed germination and seedling establishment, as well as to help in interpreting the physiological and biochemical mechanisms associated with the germination of $E$. velutina.

\section{CONCLUSIONS}

Isoenzyme expression occurs differently for the seed germination under different temperatures, with varied expression between seedlings and cotyledons. The esterase was more sensitive isoenzime analyzed; the results expressed more isoforms and different electrophoretic profile for each temperature and part of the plant evaluated.

DNA repair is more efficient during the germination of $E$. velutina seeds when submitted to a temperature of up to $25^{\circ} \mathrm{C}$, with damage to the genetic apparatus with an increase higher than this temperature. 


\section{ACKNOWLEDGEMENTS}

This study was financed in part by the Coordenação de Aperfeiçoamento de Pessoal de Nível Superior - Brazil (CAPES) - Finance Code 001. Our thanks also for support from the Laboratório de Biosementes and Programa de PósGraduação em Ciência \& Tecnologia de Sementes of the Universidade Federal de Pelotas (UFPel), Pelotas, RS, where part this study was conducted.

\section{REFERENCES}

ALFENAS, A.C. Eletroforeses de isoenzimas e proteínas afins: fundamentos e aplicações em plantas e microrganismos. Viçosa, Brazil: UFV, 1998. 574p.

BEWLEY, J.D.; BRADFORD, K.J.; HILHORST, H.W.M.; NONOGAKI, H. Seeds: physiology of development, germination and dormancy. 3.ed. Nova York, EUA: SPRINGER, 2013. 392p.

BHAVITK, K.P.; SWAMY, M.N.; SWAMY, N.R.; CHANDRASHEKHARAIAH, K.S. Purification and characterization of esterase from the seeds of Caesalpinia mimosoides. Journal of Experimental Biology and Agricultural Sciences, v.2, n.6, p.634-641, 2014. https://pdfs. semanticscholar.org/44b9/e139b4398a3c574edd5b31c85bd91c7a4e5d.pdf

BRASIL. Ministério da Agricultura, Pecuária e Abastecimento. Regras para análise de sementes. Ministério da Agricultura, Pecuária e Abastecimento. Secretaria de Defesa Agropecuária. Brasília, Brazil: MAPA/ACS, 2009. 395p. https://www.abrates.org.br/files/ regras_analise_de_sementes.pdf

CANDIDO, W.S.; MAIA, S.S.S.; COELHO, M.F.B.; SILVA, R.C.P.; SILVA, A.C. Overcoming seed dormancy of Erythrina velutina Willd. Fabaceae. Journal of Global Biosciences, v.4, n.8, p.3032-3036, 2015. https://www.mutagens.co.in/jgb/vol.04/8/040807.pdf

CARVALHO, M.L.M.; VIEIRA, M.G.G.C.; VON PINHO, E.V.R. Técnicas moleculares em sementes. Biotecnologia, Ciência \& Desenvolvimento, v.3, n.17, p.44-47, 2000.

CATÃO, H.C.R.M; GOMES, L.A.A.; GUIMARÃES, R.M.; FONSECA, P.H.F.; CAIXETA, F.; MARODIN, J.C. Physiological and isozyme alterations in lettuce seeds under different conditions and storage periods. Journal of Seed Science, v.38, n.4, p.305-313, 2016. https://doi.org/10.1590/2317-1545v38n4163863

CONN, E.E.; STUMPF, P.K. Introdução à Bioquímica. São Paulo, Brazil: EDGARD BLIICHER, 1990. p.383-385.

DOYLE, J.J.; DOYLE, J.L. Isolation of plant DNA from fresh tissue. Focus, v.12, n.1, p.13-15, 1987.

DRESCH, D.M.; MASETTO, T.E.; SCALON, S.P.Q. Campomanesia adamantium (Cambess.) O. Berg seed desiccation: influence on vigor and nucleic acids. Anais da Academia Brasileira de Ciências, v.87, n.4, p.2217-2228, 2015. https://doi.org/10.1590/00013765201520140539

DUBAL, I.T.P.; TROYJACK, C.; AISENBERG, G.R.; KOCH, F.; SZARESKI, V.J.; PIMENTEL, J.R.; NARDINO, M.; CARVALHO, I.R.; OLIVOTO, T.; SOUZA, V.Q.; VILLELA, F.A.; AUMONDE, T.Z.; PEDÓ, T. Effect of temperature on bean seed germination: vigor and isozyme expression. American Journal of Agricultural Research, v.1, n.5, p.1-9, 2016. https://www.researchgate.net/publication/317007879_Effect_of_ temperature_on_bean_seed_germination_vigor_and_isozyme_expression

GILLESPIE, J.H.; LANGLEY, C.H. A general model to account for enzyme variation in natural populations. Genetics, v.76, n.4, p.837848, 1974. https://www.ncbi.nlm.nih.gov/pmc/articles/PMC1213108/pdf/837.pdf

GONÇALVES, E.P.;FRANÇA, P.R.C.; VIANA, J.S.;ALVES, E.U.; GUEDES, R.S.; LIMA, C.R. Substrate moisture and temperature in germination of Parkia platycephala Benth. seeds. Ciência Florestal, v.25, n.3, p.563-569, 2015. https://doi.org/10.5902/1980509819607

GRABOWSKA, A.; NOWICKI, M.; KWINTA, J. Glutamate dehydrogenase of the germinating triticale seeds: gene expression, activity distribution and kinetic characteristics. Acta Physiologiae Plantarum, v.33, p.1981-1990, 2011. https://doi.org/10.1007/s11738011-0801-1

HABA, P.; MATA, L.; MOLINA, E.; AGÜERA, E. High temperature promotes early senescence in primary leaves of sunflower (Helianthus annuus L.) plants. Canadian Journal of Plant Science, v.94, n.4, p.659-669, 2014. https://doi.org/10.4141/cjps2013-276 
HENSON, C.A.; SCHRADER, L.E.; DUKE, S.H. Effects of temperature on germination and mitochondrial dehydrogenases in two soybean (Glycine max) cultivars. Physiologia Plantarum, v.48, p.168-174, 1980. https://doi.org/10.1111/j.1399-3054.1980.tb03238.x

KATO NOGUCHI, H.; YASUDA, Y. Effect of low temperature on ethanolic fermentation in rice seedlings. Journal of Plant Physiology, v.164, n.8, p.1013-1018, 2007. https://doi.org/10.1016/j.jplph.2006.06.007

KRANNER, I.; CHEN, H.; PRITCHARD, H.W.; PEARCE, S.R.; BIRTIC, S. Inter-nucleosomal DNA fragmentation and loss of RNA integrity during seed ageing. Plant Growth Regulation, v.63, n.1, p.63-72, 2011. https://doi.org/10.1007/s10725-010-9512-7

MALONE, G.; ZIMMER, P.D.; MENEGHELLO, G.E.; CASTRO, M.A.S.; PESKE, S.T. Isoenzimatic diferential expression among rice seed germination process in great depth sowing. Journal of Seed Science, v.29, n.1, p.61-67, 2007. https://doi.org/10.1590/S010131222007000100009

MARCOS-FILHO, J. Fisiologia de sementes de plantas cultivadas. 2.ed. Londrina, Brasil: ABRATES, 2015. 660p.

MERTZ, L.M.; HENNING, F.A.; SOARES, R.C.; BALDIGA, R.F.; PESKE, F.B. MORAES, D.M. Physiological changes in rice seeds exposed to cold in the germination phase. Revista Brasileira de Sementes, v.31, n.2, p.254-262, 2009. https://doi.org/10.1590/S010131222009000200031

PALUMBO, C.F.G.; GARDIN, N.E.; NAKAMURA, M.U. Erythrina mulungu Mart. ex Benth and Erythrina velutina Willd. - Pharmacological aspects and anthroposophic view of these Brazilian plants. Arte Médica Ampliada, v.36, n.4, p.152-161, 2016. http://abmanacional. com.br/wp-content/uploads/2017/06/36-4-Erythrina-mulungu-e-Erythrina-velutina.pdf

PARASA, R.; RAMAN, D.N.S.; ABHISHEK, M. Leaf and seed esterases of agathi (Sesbania grandiflora L.): purification and characterization. Biocatalysis and Agricultural Biotechnology, v.16, p.308-313, 2018. https://doi.org/10.1016/j.bcab.2018.07.013

RODRIGUES, D.R.; SILVA, A.F.; CAVALCANTI, M.I.P.; ESCOBAR, I.E.C.; FRAIZ, A.C.R.; RIBEIRO, P.R.A.; FERREIRA NETO, R.A.; FREITAS, A.D.S.; FERNANDES JÚNIOR, P.I. Phenotypic, genetic and symbiotic characterization of Erythrina velutina rhizobia from Caatinga dry forest. Brazilian Journal of Microbiology, v.49, n.3, p.503-512, 2018. https://doi.org/10.1016/j.bjm.2017.09.007

RODRIGUES, F.T.S.; SOUZA, C.N.S.; XIMENES, N.C.; ALMEIDA, A.B.; CABRAL, L.M.; PATROCÍNIO, C.F.V.; SILVA, A.H.; LEAL, L.K.A.M.; HONÓRIO JÚNIOR, J.E.R.; MACEDO, D.; VASCONCELOS S.M.M. Effects of standard ethanolic extract from Erythrina velutina in acute cerebral ischemia in nice. Biomedicine and Pharmacotherapy, v.96, p.1230-1239, 2017. https://doi.org/10.1016/j. biopha.2017.11.093

SANO, N.; RAJJOU, L.; NORTH, H.M.; DEBEAUJON, I.; MARION POLL, A.; SEO, M. Staying alive: molecular aspects of seed longevity. Plant Cell Physiology, v.57, n.4, p.660-674, 2016. https://doi.org/10.1093/pcp/pcv186

SANTOS, C.M.R.; MENEZES, N.L.; VILLELA, F.A. Physiologic and biochemical modifications during storage of bean seeds. Journal of Seeds Science, v.27, n.1, p.104-114, 2005. https://doi.org/10.1590/S0101-31222005000100013

SCANDALIOS, J.G. Genetic control of multiple molecular forms of enzymes in plants: a review. Biochemical Genetics, v.3, p.37-39, 1969. https://doi.org/10.1007/BF00485973

SOUSA, R.F.; OLIVEIRA, Y.R.; CALOU, I.B.F. Anxiety: general aspects and treatment with focus on plants with anxiolytic potential. Revinter, v.11, n.1, p.33-54, 2018. http://autores.revistarevinter.com.br/index.php?journal=toxicologia\&page=article\&op=view\&path\%5B\%5D=327

TUNES, L.M.; BADINELLI, P.G.; BARROS, A.C.S.A.; MENEGHELLO, G.E.; AMARANTE, L. Influence of different harvest times on isozyme expression in barley seeds. Ceres, v.58, n.2, p.178-184, 2011. https://doi.org/10.1590/S0034-737X2011000200008

VIEIRA, B.G.T.L.; BARBOSA, R.M.; TREVISOLI, S.H.U.; MAURO, A.O.; VIEIRA, R.D. Biochemical alterations in soybean seeds with harvesting time and storage temperature. Journal of Food, Agriculture and Environment, v.11, n.3, p.887-891, 2013. https://www.researchgate. net/publication/262132741_Biochemical_alterations_in_soybean_seeds_with_harvesting_time_and_storage_temperature

WATERWORTH, W.M.; BRAY, C.M.; WEST, C.E. Seeds and the art of genome maintenance. Frontiers in Plant Science, v.10, p.01-11, 2019. https://doi.org/10.3389/fpls.2019.00706

WEITBRECHT, K.; MÜLLER, K.; LEUBNER METZGER, G. First off the mark: early seed germination. Journal of Experimental Botany, v.62, n.10, p.3289-3309, 2011. https://doi.org/10.1093/jxb/err030 